\title{
Aesthetic Universals in Neil Gaiman's Post-Postmodern Mythmaking
}

\author{
Ivan Čipkár \\ Palacký University Olomouc, Czech Republic
}

Aesthetic theory, as reflected in both contemporary cognitive (Patrick Colm Hogan) and more traditional structuralist criticism (H.G. Widdoweson), points to the dynamics between familiarity and surprise as the driving force behind the pleasure we derive from reading fiction. This paper explains how Neil Gaiman's works, particularly his novel Neverwhere, utilize genre expectations and reinvent mythologies in order to captivate audiences in the current age of unprecedented access to information and a rather superficial intertextuality. The paper draws on Brian Attebery's analyses of the literature of the fantastic to place Gaiman within the context of both modernist and postmodernist legacies, while proposing that his works could be best understood as representative of the current cultural paradigm, sometimes labelled as the pseudomodern or post-postmodernism. The discussion of the shifting paradigm is used as a backdrop for the scrutiny of the devices employed in Gaiman's writing: the pre-modern focus on storytelling, prototypicality, modernist "mythic principle", postmodernist textual strategies, and utilization of current technologies and mass-communication media.

\section{Keywords}

Literary universals; myth; Neil Gaiman; postmodernism; post-postmodernism; pseudo-modern

This affinity between the mythical and the abstractly literary illuminates many aspects of fiction, especially the more popular fiction which is realistic enough to be plausible in its incidents and yet romantic enough to be a "good story" (Frye 139). 


\section{Harmony and Dissonance as Means of Aesthetic Effect}

In his essay on the significance of poetry, H. G. Widdowson talks about the two conditions which need to be satisfied in order for a poem (or any piece of literary art for that matter), to be aesthetically effective. "The first is that it disperses meanings and disrupts established ideas, or what T. S. Eliot referred to as 'stock responses'. This we might call the destructive or divergent condition" (61). In plain terms, Widdowson talks about the elements of artistic expression which give rise to surprise or defy expectations. The more a work of literary art is incongruous and "difficult to accommodate within accepted structures of reality", the greater its aesthetic potential. We find many examples of works within the traditions of the postmodern and high modernism which have garnered critical acclaim based partly on the satisfaction of this condition. However, this has also led to a reputation of incomprehensibility for many modernist and postmodernist authors from the point of view of the general public, a sentiment that is echoed by Paul B. Armstrong in his book on neuroscience and literature: "No matter how often I read Ulysses, it remains more difficult and resistant to comprehension than some novels in the realistic tradition that I nevertheless also value highly - novels that have their own subtleties and complexities, to be sure, but that facilitate integration more than puckish, rebellious James Joyce does" (46).

Since it is more than dubious to equate pure obscurity and incomprehensibility with aesthetic quality, Widdowson introduces the second, "convergence" condition: "The incongruity of the poem and the disruption it causes have to be made congruous, the disorder reassembled into a different order. The more patterning that one can discern $[\ldots]$ the more integrated the patterns, the greater its aesthetic potential" (62). Again, this condition alone would not suffice, otherwise regularity could be equated with quality. It is only through a delicate balance of the two that a work of art can function as an effective aesthetic experience: "patterned" enough so as to "facilitate integration" in the reader's mind, but also retaining its originality - its dissonant features - which would make it worthy of such integration.

In cognitive science, this balance has an analogue in the concepts of prototype approximation vs. violation of expectations. If modernist experiments rely mostly on the latter, the former is constitutive of kitsch. ${ }^{1}$ In a study exploring the brain's reaction to music, Vuust and Kringelbach indicate that "anticipation/prediction could act as some of the fundamental mechanisms underlying musical structuring and that this taps into the way 
that the brain works on different levels with a capacity to evoke pleasure in humans" (266). Familiarity of structure and the predictability of outcomes of musical sequences activating the reward system of the brain could thus conceivably account for the success of much of the output of contemporary popular music.

Hogan claims that this principle, which may be construed as a form of prototype approximation, holds true more generally. He also points out that predictability and repetition cause us to lose interest, and he contrasts the anticipatory principle with violation of expectations: "It seems that aesthetic pleasure is more likely to derive from partial unexpectedness that, within some window, allows for retrospective pattern recognition" (26). Hogan proposes a synthesis of the two contrary principles and coins the term "non-anomalous surprise", explaining that "it is surprise because we do not specifically and self-consciously anticipate the outcome, at least not with confidence. However, it is not anomalous because we are able to recognize the pattern once it occurs" (27).

Similar views can be found in works of other contemporary cognitive scholars. Armstrong points to the disagreement between Roman Ingarden, the trailblazer in phenomenological aesthetics, and the later Wolfgang Iser's and Hans Robert Jauss's school of reception theory, concerning whether aesthetic pleasure stems from "a harmonization of felt values" or "a disruption of the reader's expectations". Instead of taking sides, he decides to examine the bigger picture, claiming that "neuroaesthetics should ask how these accounts of the pleasures $[\ldots]$ of having expectations met or thwarted are related to the brain's processes of comprehension" (23). Studies of the importance of harmony for aesthetic pleasure would be concerned with neurological functions responsible for pattern recognition, while the neurological correlative to surprise should be identified in the systems of the brain which process and integrate unfamiliar experiences.

If we ponder the problem of how the principle of non-anomalous surprise applies to literary analysis, there arise practical questions pertaining to the functioning of this balance between surprise and familiarity when considered in the context of a particular literary work. Hogan tries to answer this question by attributing complementary distribution to the two principles, or "by positing different sorts of aesthetic processing for focal and non-focal aspects of the aesthetic target. Focal aspects would then be pleasurable to the degree that they foster non-anomalous surprise, whereas non-focal aspects would be valued primarily for predictability" (27). The goal of a literary researcher would 
then be to assess, in the process of close reading, the "focality" of the aspects comprising a given piece of fiction or poetry. To this end, lacking a more precise, neuroscientific from of enquiry, they could conceivably arm themselves with one of the structuralist, narratologist, reception, cognitive-poetic or other theories honed by the instincts of scholars who came before them.

\section{Gaiman's Hero's Journey in Neverwhere}

Neil Gaiman is widely considered as one of the modern mythmakers who, rather than create fantastical worlds from scratch, utilize both Western and Eastern mythologies, adapting them to present-day readers' sensibilities. His adoption of motifs from myth, folk and fairy tales or even bodies of work by modern authors which have acquired a quasi-mythical status (like those of H.P. Lovecraft or Arthur Conan Doyle) feature in stories with relatable contemporary characters dealing with mundane troubles. While keeping the topics relatable, the author manages, at the same time, to tackle timeless topics, echoing millennia of storytelling tradition.

Gaiman, who has consciously avoided reading Joseph Campbell's influential monomyth theory ${ }^{2}$, nevertheless succeeds in fitting into its precepts. A striking example of this is Gaiman's first single-author novel, Neverwhere (1996), a seminal work of urban fantasy, in which Richard Mayhew, an investment analyst, finds himself on a journey through the bowels of "London Below", an alternative reality both perilous and wonderful, located in the sewers and the underground system of the actual city of London. Richard, in whom the reader finds a complacent, middle-class, Generation X member of post-modern society (in other words: someone with whom the model reader can readily identify), is to rediscover the timeless truths concerning a man's place in the world - not by the means of institutionalized, ritualized proxy, but by literally going through the actual trials of a mythical hero.

The fact that Gaiman has been asked about Campbell by journalists in interviews, and that fans and scholars alike connect him to Campbell's work informs us of two things: the first one being the readiness with which Gaiman's readers are reminded of Campbell's theory; the second one being the undying popularity of this American scholar, who managed to combine insights form folklore, anthropology, comparative religion and literature to create an appealing universal narrative framework.

Reading Gaiman through the lens of Campbell is hardly a novel idea, and 
the fact that the Hero's Journey is often applied in analysis of his texts (see Rauch or Delahay) is indeed no coincidence. Gaiman is quite conscious of his designation as a modern mythmaker, which is to a great degree self-appointed. In his essay on the role of myth in our lives, he writes that his comic-book tour de force "The Sandman was, in many ways, an attempt to create a new mythology - or rather, to find what it was that [he] responded to in ancient pantheons and then to try and create a fictive structure in which [he] could believe as [he] wrote it. Something that felt right, in the way that myths feel right" ("Reflections on Myth" 77).

\section{Gaiman between Archetype and Divergence}

As both Hogan and Widdowson argue (see opening section), familiarity stemming from pattern recognition is a fundamental part of a "successful" aesthetic experience. Since literature is necessarily anthropocentric, particular care should be ascribed to the study of empathy and processes which enter the act of identification or "feeling into" a literary character.

We can hardly talk about any emotional connection between the fictional reality and the reader if the characters' actions do not make sense to him or her; and, in turn, "the actions of others" (Schank and Abelson 67) - regardless whether the "others" in question are real or fictional, mentally construed characters - "make sense only insofar as they are part of a stored pattern of actions that have been previously experienced" (67). This would underline the strong connection between prototypicality, narrative structures which have cross-culturally stood the test of time, and aesthetic effectiveness. Schank and Abelson warn us that "deviations from the standard pattern are handled with some difficulty" (67), but, as was noted previously, it is these deviations which are necessary for the creation of an original and aesthetically effective work - which brings us back to the other one of Widdowson's conditions: divergence. The problem of the delineation of the two conditions should be understood as a delineation of domains which comprise a literary work - in terms of structure, style (voice), etc.

In the narrative structure of Neverwhere, there could be identified familiar patterns and traditional storytelling tropes, whether we adapt Campbell's or some different universalist analysis. This is the side of Gaiman's novel which utilizes prototype approximation and gives rise to the feeling of harmony, convergence and regularity. Reader's expectations are met and their projected 


\section{IVAN ČIPKÁR}

desires satisfied. The potential risk of tedium is averted by the other side facets including the originality of the setting, or Gaiman's unmistakable penchant for turning the timeless into the topical, the uncanny into the homely, and the mythological into the intimate, many times utilizing irony and playful intertextual referentiality.

An apt example of this playful ironic approach is a character featuring prominently throughout the story of Neverwhere: the Marquis de Carabas, a man who guides Richard on his journey through the undercity, dispensing advice and sarcasm alike. He is first described wearing "a huge dandyish black coat ... and high black boots" and walking "restlessly up and down the alley [...] like a great cat" (46), reminiscent of Perrault's Puss in Boots, the fairy tale character that helped a young miller to fame and fortune. He later admits that, indeed, "he had named himself from a lie in a fairy tale ... and created himself as a grand joke" (239).

Another example of divergence from expectation is the novel's treatment of the real-world London setting and how it is utilized to build a parallel reality, much in the same fashion as the Marquis constructs his identity through a joking reference. Richard's trip through London Below takes him to places with familiar names - they are mostly the stations of the London Tube - but there is always present a certain twist which endows the location, in its "magical" rendition, with a new meaning. Such revelations evoke the feeling of the uncanny3 by making the various real-world locations' names literally tied to an existence of a character or place revealed in the story. These include places such as the Night's Bridge (a play on the name of the tube station "Knightsbridge"), Earl's Court (referring not to the station, but, in a humorous twist, to a number of train cars moving around the underground system, magically hidden from the sight of ordinary Londoners, occupied by the Earl and his courtiers), Islington (being the house and prison of the angel Islington), Blackfriars (the etymology of which - derived from an old Dominican priory - is actualized by the presence of an underground monastery occupied by friars dressed in black sackcloth), Old Bailey (referring, rather than to London's Central Criminal Court, to a peculiar character inhabiting the "other London's" rooftops), etc.

In this fashion, Gaiman reinforces the notion that things we have grown accustomed to may not be what they seem, and, by the juxtaposition of the wondrous and the commonplace, he draws attention to the symbols underlying our millennia-long experience with the world. It can be said, in the words of Susana Onega, that Gaiman uses "parody, pastiche and metafictional 
undermining of realism-enhancing mechanisms to suggest the fragmentation $[\ldots]$ of the self, while simultaneously attempting to transcend this isolation and fragmentation in mythical and archetypal terms" (187). The notion of "fragmentation" should be understood here in two ways. First, a fragmented person, such as the Marquis, or a location, such as one of the sites of London Below, should be understood as a collection of figments, modulated (in a very postmodernist fashion) by the point of view - they can unexpectedly show themselves to be their own antithesis, or prove to be more literally themselves (thesis: Blackfriars is named after actual friars living there; antithesis: it is just a name; synthesis: the friars are really there after all). Second, this implicit fragmentation can foreground the questions of reality: What is the true nature of the thing? Could its fakeness make it somehow more genuine? Gaiman's answer appears to be: that which is more "mythical and archetypal" (i.e., more aesthetically satisfying) is the "truer" thing.

A different, more straight-forward way to account for these creative choices would be to point to the author's sheer love of stories and of all kinds of embedded narratives - and to his readiness to share this love with his audience, which creates the context for his sustained reflection on the art of storytelling and on the importance of "narrative understanding of the world" in our lives - a theme which has entered the focus of cultural inquiry (in academia and elsewhere) with the coming of postmodernism.

Gaiman's affinity with the postmodern is persuasively demonstrated in Sandor Klapcsik's treatise of liminality in fantastic fiction. He points out that Neverwhere "demonstrates contemporary Foucauldian theories, emphasizing that visualizing, narrating, and rendering visible are always controlled by psychological, cognitive, historical, and social factors" (56). This is most manifestly represented in the passage in Neverwhere where Richard becomes invisible to the denizens of the "real" London, who are unable to detect anyone belonging to London Below or keep them in their consciousness long enough to accomplish any meaningful social interaction. "The isolation of the protagonist [...] from London Above is of cognitive origin: people living in consensus reality simply ignore him, in the same way as they ignore everyone who belongs to the (under)world of homelessness or that of the fantastic" (77).

The above posits Gaiman among the contemporary postmodern storytellers of the speculative genre, each of them reflecting "postmodernism's selfconsciousness about storytelling and employing its typical disruptions of genre and violations of textual boundaries", features we see in the works of writers 
such as Alan Garner, Jeanne Larsen, Molly Gloss, and Ursula K. Le Guin (Attebery 8). Still, formal experimentation in Gaiman and his counterparts remains modest, and their style certainly cannot be lumped besides textbook postmodernist like Barthelme and others who are so reminiscent of the great masters of modernism such as Eliot and Joyce. At the end of the day, as Gaiman himself has expressed in the past, the primary consideration for him has always been to satisfy the audience reading, viewing, or listening to his storytelling by providing them with (at least an opportunity for) a meaningful narrative conclusion (Lisa-Ann Lee). ${ }^{4}$

And, indeed, it might be these readers' satisfaction which can make a literary work stand the test of time, as Jane Tompkins argues in her work on popular $19^{\text {th }}$ century American fiction, against the "modernist demands for psychological complexity, moral ambiguity, epistemological sophistication" etc. (xvii), or, more significantly (and more relevantly, since this is fantasy literature we are talking about ), despite its "excessive reliance on plot, and a certain sensationalism in the events portrayed" (xii). Tompkins emphasizes social and historical context as the factors of the making of a great novel; factors, we might add, in which certain universal tendencies might be reflected, thus accounting for a given work's lasting value. "For a novel's impact on the culture at large depends not on its escape from the formulaic and derivative, but on its tapping into a storehouse of commonly held assumptions, reproducing what is already there in a typical and familiar form" (xvi). Tompkins's "embrace of the conventional" led her to value "everything that criticism had taught [her] to despise: the stereotyped character, the sensational plot, the trite expression" (xvi). This trinity of "low-brow" literary satisfaction warrants a breaking-down. First, let us consider the stereotypical hero.

The character of Richard in Neverwhere is certainly an everyman character, an inconspicuous member of the middle class white-collar echelon; even the fact of his Scottish origin is little more than a superfluous detail. He is made great by what he does - his role in the grand scheme of things, the accomplishments of his hero's journey - not by what he is. He does not possess any unique traits which would predestine him for his journey, and this is precisely what makes him so appealing and readily identifiable with. ${ }^{5} \mathrm{He}$ is Neil Gaiman (whose middle name is, interestingly enough, Richard) after one has removed everything which makes Neil Gaiman exceptional. ${ }^{6}$

On the other hand, there is another character present in the novel reflective of the author's self: the Marquis de Carabas, the "grand joke", his identity a metafictional play, self-constructed the way a master storyteller, informed 
by a lifelong love of books, spins a tale. Then there is Hunter, the warriorhuntress who has come to London Below to hunt down the legendary beast which lurks in the sewers, catacombs, forgotten cellars and abandoned WWII shelters which comprise the undercity. She is an overt representation of her role, a prototype made flesh, with little more than cosmetic attempts (being female rather than the more stereotypical male) to hide it. There is also the Lady Door, who, while playing the role of the damsel in distress, is in need of saving not because of any incapability of hers, but because of the awesome forces seeking to do her harm. Even the antagonists, Vandemar and Croup, are written with Gaiman's writer maxim of creating characters one would enjoy talking to at a party ("Neil Gaiman: Man in Black"). While Gaiman arguably utilizes prototypical character roles, his characters are far from stereotypical.

When it comes to "sensationalism" of plot, there can be hardly any argument against its presence in a book filled with magic, angels, deathless assassins, giant boars, intelligent rats and many other wonders. Finally, as has been demonstrated earlier, Gaiman's "expression", while at times deceivingly straight-forward, shares features of both great traditional storytellers and postmodernist works. Could this peculiar mix of the postmodern, the Victorian, and the fantasist currents within modernism be symptomatic not only of Gaiman's particular style, but also represent a sign of the times which are replacing the dominant postmodern paradigm? Gaiman's stellar rise in the late 8 os and early gos coincides with what could be called the beginning of a new era - politically, of course, but also culturally - "the contemporary period starting with the fall of the Berlin Wall in 1989 and gathering momentum throughout the 1990 os and beyond - is often said to have a distinct intensity" (Gibbons par. 1):

Indeed, in place of postmodernism's cool detachment, its antianthropomorphism, realism is once again a popular mode. Emotions, furthermore, are again playing a central role in literary fiction, as authors insist on our essential relationality - our connectedness as humans to one another in the globalizing world and with fictional characters as representations of our selves. (Gibbons par. 4)

Without going too deeply into a discussion of postmodernism itself, we can draw some preliminary conclusions about the coming paradigm if we identify the features of postmodernism which the new cultural current responds to. 
The crucial aspect of postmodernism, famously formulated by Jean-Francois Lyotard, is its distrust of grand narratives and universal truths. Lyotard defines postmodern as "incredulity toward metanarratives", pointing out that "the narrative function is losing its functors, its great hero, its great dangers, its great voyages, its great goal" (xxiv), i.e., exactly the features by identification of which Campbell founds his theory and which serve contemporary cognitive literary scholars as indices of narrative universals.

\section{Gaiman between the Modern and the Postmodern}

If Neil Gaiman's generation of fantasists pushes against the de-stabilizing, de-legitimizing, relativizing forces of the postmodern, there surely must be a principle of unity and universality to be identified in their work - above, I have tried giving an approximation of an account of where the search for such a principle should begin. If the modern and the post-modern truly repeat themselves as alternating phases in cultural history, one always responding to the other (see Lyotard 79), there ought to be parallels between the coming paradigm and that of modernism. In fact, Brian Attebery readily identifies a point in modernism where such a parallel could begin; in his attempt to make sense of the role of the apparently anachronistic Inklings within the paradigm defined by Eliot, Pound and Joyce, he argues that, far from J.R.R. Tolkien's or C.S. Lewis's work standing for a rejection of the modern, it represents, rather, one of its defining facets (42). Here Attebery points to Eliot's essay about Ulysses, and his proposed idea of the "mythic principle":

In using the myth, in manipulating a continuous parallel between contemporaneity and antiquity, Mr. Joyce is pursuing a method which others must pursue after him. [...] It is simply a way of controlling, or ordering, of giving a shape and a significance to the immense panorama of futility and anarchy which is contemporary history. [...] Psychology, ethnology, and The Golden Bough have concurred to make possible what was impossible even a few years ago. Instead of narrative method, we may now use the mythical method. It is, I seriously believe, a step toward making the modern world possible for art. (Eliot 177-8)

Of course, Eliot espouses the mythic principle in his own poetic work as well. For Attebery, whose second chapter of his comprehensive search for the 
essence and roots of the contemporary fantasy genre explains the debt the genre owes to modernism, the crucial mythic source in "The Waste Land" is Arthurian legend:

Eliot uses both the pagan and Christian aspects of the [Grail Quest] story to construct a guide through and a commentary on a set of scenes from contemporary life. To represent the latter, Eliot combines pastiche and parody with imagistic detail and wistful lyricism (deliberately roughened up by Ezra Pound's editing). The myth appears mostly in the form of oblique allusions (reinforced by the notes) and Janus-faced characters: modern types who are also degraded versions of gods, magicians, and heroes. (44)

It is striking how the same description could be used to characterize Gaiman's work. While the particulars in the selection of mythical and religious sources may differ, the method of using these "inherited" frameworks "to construct a guide through and a commentary on a set of scenes from contemporary life" can certainly be identified in most of Gaiman's work. The reverse could also be argued: in Neverwhere and American Gods, we might also find evidence of Gaiman making a commentary on mythic (or otherwise timeless) topics using scenes from contemporary (British and American, respectively) life.

We have already noted how (e.g., in the playful utilization of the names of the London underground stations and other place-names) pastiche and parody play an important role in Neverwhere. Another striking characteristic that expresses the essence of Gaiman's brand of contemporary fantasy is the characters, "Janus-faced [...] degraded versions of gods, magicians, and heroes". This is not only the fundamental idea behind American Gods, it is also a method widely utilized by Gaiman in the entirety of his imaginative work. In Neverwhere, the break between the magical, anachronic world of London Below and the "real" world is rendered clean by the limits Gaiman puts on the interaction between the two (exemplified by Richard's sudden invisibility to the inhabitants of the "real" London after his dealings with the magical realm take place), while elsewhere (in American Gods), the two are intricately enmeshed - which appears to be truer to Eliot, more closely espousing his mythic method.

Attebery wonders how "The Waste Land" would look if it were, instead of a "densely allusive and cryptically fragmented poem", a novel. $\mathrm{He}$ conjects: 
Such a novel would juxtapose the Holy Grail and sterile urban life; there would be charlatans masquerading as real prophets and vice versa; characters would undergo spiritual crises and transformations; there would be sinister Easterners and scenes of sexual degradation; visions of hell would be counterpointed with moments of redemption; the desired and forbidden other would be expelled. Novelistic discourse could fill in the gaps left in Eliot's poem, or at least seem to, with realistic settings, dramatic scenes, internal monologues, and a plot. It would not matter too much what sort of plot: the function would be to carry readers along and perhaps distract our attention while the symbols did their work. The novel could be a romance, an adventure, or perhaps a detective story. (46)

One of Gaiman's short stories, "Chivalry”, features a retired lady (a stereotype of the grandmotherly English middle-class pensioner) buying an old chalice at an Oxfam shop, which turns out to be the Holy Grail when an entirely anachronistic Arthurian knight appears at her doorstep to solicit the legendary relic from her. As to "real prophets" masquerading as "charlatans", the powerful characters and keepers of profound knowledge or awesome magic in Gaiman's writing usually assume the form of the unassuming, the inconspicuous, and the easily overlooked. The most typical instance or this would be the domesticity which covers up the unfathomable power of the Hempstock family in The Ocean at the End of the Lane. Neverwhere drives the point to its extreme by rendering its varied cast of characters, many of whom are endowed with wondrous abilities, by portraying them as - or very close to - vagrants, the invisible class.

What Attebery designates as "spiritual crises and transformation" is conveniently broad to incorporate any number of situations; let us name at least Richard's "falling through the cracks", his trial at the Black Friars, or his facing and defeating the Beast of London - the important milestones on his "hero's journey". Where this meta-interpretative comparison diverges, however, is with the "sinister Easterners" and the Freudian precept of the expulsion of "the desired and forbidden other"; and it is hardly surprising that we cannot find equivalents of Eliot's anti-Semitic undertones in Gaiman, who is descended from East European Jewish emigrants. On the contrary, instead of expulsion we find integration, albeit this integration is never complete, as could be demonstrated by the shadowy inhabitants of London Below, whose existence is not known or acknowledged in the "real" London, or by the various deities living in the American Gods' United States - integrated, but not able to live up to their full potential. Gaiman's stories are stories 
of people on the margins. Where Eliot's sinister Jews are reminiscent of the anti-Semitic reading of Dracula, Gaiman's "vampires" (in a more general sense of any wondrous creature) are humanized, although not completely domesticated - they maintain their "liquid" characteristics (see Čipkár 33).

Following Attebery's thought experiment a little longer, we see that he argues for a variety of genres to be conceivable if Eliot's method in "The Waste Land" is utilized in prose - indeed, if aspects of it are rewritten as a novel: a romance, an adventure, or a detective story. Even though they usually occupy the shelves of the fantasy section in bookshops, we can certainly find all of the above-mentioned genres in Gaiman's novels and collections of short stories. Romance is ever-present and, as is the case with most works in the fantasy genre, everything is centered around an adventure (the only caveat being that in Gaiman this adventure might be implicit, taking the form of a more mundane set of scenes from everyday life). The usability of the mythic method for the detective genre can be demonstrated by a number of stories in which Gaiman borrows Arthur Conan Doyle's classic character of Sherlock Holmes, or by the very title of the story "Murder Mysteries", which portrays an investigation of a crime - the original crime, in fact - in heaven.

Gaiman's push for reflection and highlighting of marginalized voices, as seen in his utilization of homelessness as a constitutive theme and metaphor in Neverwhere, his smattering of ethnic narratives and indigenous mythologies in American Gods or Anansi Boys, or his lesbian romance twist at the end of The Sleeper and the Spindle are certainly elements the analogues of which could be found elsewhere in the postmodern tradition - vis-à-vis, for example, Eliot's authoritative, unifying vision, or C.S. Lewis's religiosity, or Tolkien's straightforward boyish fantasy. But while postmodernism is "overlapping in its ends and means with feminism and postcolonialism, as well as with queer, race and ethnicity theory", it is "by no means interchangeable" with them (Hutcheon 166). Hutcheon hints but never goes as far as to assert how postmodernism could be complicit in legitimizing the prevailing modes of control, "fully institutionalized" with its "canonized texts, its anthologies, primers and readers, its dictionaries and its histories" (165), becoming more and more enmeshed with the enterprise of global capitalism. Far from liberating, the relativizing, self-deconstructing cacophony of contending voices has served to obfuscate universal emancipatory goals, and led to "an ensuing disillusionment with the project of neo-liberal postmodernity" (Gibbons). Hutcheon points to the postmodern's "lack of a theory of agency", reflecting one of the major objections on the part of feminist theoreticians and practitioners, a dimension 
"so crucial to the interventionist dimensions of working for change" (171). It would seem that the reign of the postmodern has created a new need: something to orient oneself by, as opposed to postmodernity's feeling of "disorientation" (175); and this, precisely, is where the mythic principle can enter, bringing with itself a "rehabilitated ethical consciousness" (Gibbons).

\section{Gaiman between the Postmodern and the Pseudo- Modern}

A decade ago, Alan Kirby proclaimed postmodernism "dead and buried", noting how "the people who produce the cultural material which academics and nonacademics read, watch and listen to, have simply given up on postmodernism" and lamenting the level to which "postmodernism has sunk; a source of marginal gags in pop culture aimed at the under-eights". Even a cursory review of the traditional mainstream media and the new Internet media, including social networks, reveals that the most substantial postmodernist production currently takes place in Facebook groups and on Internet message boards, and consists mostly of teenager-produced commentaries on a range of topics, from various pop-cultural events to everyday adolescent experience, mostly in the form of stock images combined with ironic or jocular captions added by the creators. At the same time, the primary cultural material (films, TV shows, music recordings) which these contemporary young "postmodernists" reference remains formally conservative, and its postmodern character is preserved only in the occasional nostalgic wink to the audience. ${ }^{7}$ Even such a brief evaluation demonstrates what Kirby predicted to be the defining characteristic of the postmodern's successor - the pseudo-modern - i.e., interactivity (most noticeably exemplified by the rise of the Internet, reality TV shows, and videogame culture).

One uniquely pseudo-modern phenomenon, which Kirby overlooks in his analysis (probably because its interactivity is more oblique than the one in video games and reality shows), belongs to the literary world, or, at least, to its margins; it is fan fiction, a unique form of creative interaction where the role of author and reader are displaced. Neil Gaiman has called fan fiction an activity useful for "honing writing skills", but he ultimately thinks of it as "training wheels. Sooner or later you have to take them off the bike and start wobbling down the street on your own" (Neil Gaiman's fournal). He has repeatedly claimed ("Neil Gaiman's Opinion on Fanfiction") - excepting legal 
and commercial considerations - not having a strong opinion of fan fiction, both in general and regarding imitations of his own works. In contrast to his view of fan fiction as "training wheels", something an author outgrows over the course of becoming a professional, many of his own works could be considered fan fiction - except, they are done in collaboration with the copyright holders or on commission (as is the case with Gaiman's various short story and screenwriting excursions into the world of Doctor Who or the various DC universe franchises), or using material in the public domain. The latter includes his stories featuring Sherlock Holmes, "The Case of Death and Honey" and the Lovecraftian crossover "A Study in Emerald", the former the Doctor-Who-episode-shaped adventure story "Nothing O'Clock". In the market-oriented, digital era of the pseudo-modern, this age-old creative practice becomes more explicit: literary fans become writers, and writers are often writers of fan fiction. As Kirby notes, in the pseudo-modern, forms of enjoyment and creation which were always there but at the margins, begin to dominate.

A notable event in Gaiman's creative life illustrating the manner in which various cultural endeavours of the current age generate the "pseudo-modern illusion of participation" (Kirby) was his A Calendar of Tales. In February 2013, Gaiman, in collaboration with BlackBerry, as a part of BlackBerry's "Keep Moving" promotional project, asked Twitter users twelve questions about the months of the year; then he selected one answer for each month, utilizing them as inspirational hooks for twelve short stories. Having written the twelve short stories, he invited artists to illustrate them. It should be noted that, while at its heart this was a collaboration of a professional writer and a group of his talented semi-professional artist-followers, the accompanying hubbub on the social networks (as of early 2019, the number of Gaiman's Twitter followers adds up to 2.6 million) created an air of "being a part of something greater". Thousands of people whose actual input might have been minimal (limited to a single tweet), maybe not greater than the usual level of activity of those partaking in reality-show-style entertainment or sports events, had a sense of participation. The utilization of Twitter (an outlet the significance of which for the contemporary global culture could be summed up in the sole fact that it is the communication channel of choice for the current most powerful man on earth) as a platform for creation is indicative of what Kirby claims to be the defining aspect of the pseudo-modern: "the pseudo-modern text, with all its peculiarities, stands as the central, dominant, paradigmatic form of cultural product today $[\ldots]$ the activity of pseudo-modernism is electronic, and textual, 
but ephemeral. [...] it forms the twenty-first century's social-historical-cultural hegemony" (Kirby).

The reason why Kirby's analysis, when applied to the subject of popular contemporary writers such as Gaiman, comes short, however, is twofold. The first one is his concentration on the most popular and "vulgar" expressions of pseudo-modernism (TV reality shows, pop music, literary bestsellers, pornography), the importance of which is highlighted by the conspicuous technological changes of the media used to distribute and consume them. The second part of the reason is Kirby's formulation of the pseudo-modern in almost purely antithetical terms with regards its predecessor, which is valuable in order to highlight and isolate the specific characteristics important for a better understanding of the cultural changes which are now underway, but could, in the context of actual textual analysis, resemble (as was the case with much of literary theory throughout the ages) pushing an intricate and largely amorphous cultural reality through a convenient cookie-cutter.

Whatever the characteristics of the pseudo-modern turn out to be, it would be safe to assume they include a hearty dose of whatever defined its predecessor. Thus we can remain sceptical to assertions such as: "Whereas postmodernism called 'reality' into question, pseudo-modernism defines the real implicitly as myself, now, 'interacting' with its texts. Thus, pseudo-modernism suggests that whatever it does or makes is what is reality, and a pseudo-modern text may flourish the apparently real in an uncomplicated form" (Kirby). While Gaiman himself claimed that one of the reasons for the rising success of the fantasy genre among the popular readership was fatigue with the modernist formal experimentation ("Whose Fantasy?"), and while the streamlining of form appears to be a conspicuous characteristic of his own material as well (i.e., it is by and large written in uncluttered, limpid language, devoid of any formal experimentation), his work also runs contrary to Kirby's idea about the pseudo-modern's claim to reality - the here-and-now legitimized by the very reality of the reader's interaction with the text.

A constitutive element of Gaiman's writing is the constant re-negotiation of reality on the part of both the characters and the reader. This includes Richard's struggle to come to terms with the uncanny duality of all the places in London he previously thought familiar in Neverwhere, or the double nature of the gods and other magical creatures in American Gods. Neither a magical, nor a realistic reading of the events satisfies on its own - it is precisely the interplay of doubts and hesitation between the apparently conflicting ways of viewing 
reality which makes the reading experience memorable. The alternate realities feed off each other, provide commentary of one another, and evoke metafictional questions about narrative phenomena as such, much in the tradition of the postmodern questioning of reality and the text-reader interaction.

If we were to identify a unifying, over-arching theme, or style, in Neil Gaiman's writing, it would be the obsession with "story-shape", with the importance of narrative, the story-ization of everyday life. In his public speeches, essays, in his online journal, and on social media, Gaiman explicitly states that which he conveys implicitly in his storytelling: his stories are, at the end of the day, stories about stories. This is apparent on a rather superficial level from his abundant use of references to other writers and works of literature ancient and contemporary, his metafictional embeddings and intertextuality. On a deeper level, his almost ubiquitous utilization of fantastic elements appears to, first and foremost, stress the fictionality - the quality "of being a story" - of his works; these elements make the fictionality of his short stories, novels, comics, and other creations overt, the ultimate message being: people (and Gaiman, the representative storyteller and story-reader, in particular) like things to be story-shaped. We process our experience narratively, and stories imbue our lives with meanings. Gaiman manages to celebrate this principle covertly in his subtle metafictions, creating stories which ultimately point to other stories: to the literary, the imaginative, and the fantastic, as a whole.

\section{Notes}

1. The list of defining elements constitutive of kitsch, given by Tomáš Kulka, is comprised of: 1. strong emotional charge [giving rise to] immediate non-reflexive action, 2. simplicity, and 3. stereotype (115). He quotes Milan Kundera's definition of kitsch as a "categorical agreement with being" (116). Kitsch does not pose questions, it gives an answer; it is incompatible with irony and doubt (117), which makes it the antithesis of the avantgarde (including modernism and postmodernism, which, while it can utilize kitsch, never does so whole-heartedly).

2. "I think I got about half way through The Hero with a Thousand Faces and found myself thinking if this is true - I don't want to know. I really would rather not know this stuff. I'd rather do it because it's true and because I accidentally wind up creating something that falls into this pattern than be told what the pattern is" (Gaiman and Ogline).

3. For the definition of the uncanny, see Freud 120-62.

4. Gaiman comments on his encounter with one of the most enigmatic and surreal filmmakers of our time, David Lynch. Debating a possible collaboration, Gaiman's and Lynch's different approaches to narrative art quickly became apparent. 


\section{IVAN ČIPKÁR}

5. Gaiman admits this himself, when he quotes, in an interview, C. S. Lewis's maxim concerning heroes and Everyman - the idea that a hero in a novel should not be "too odd", since "how odd events strike odd people is an oddity too much. [...] I wanted a hero who $[. .$.$] was a little bit everybody" ("A Conversation with Neil Gaiman").$

6. "For me, one of the tricks to writing is to base all of my characters on me. Which means that when I want a villain I tend to start with me. Just as when I want a hero I tend to start with me" ("Neil Gaiman: Man in Black").

7. Examples from television would include the 1980 os nostalgia in the show Stranger Things (2016) or the Lovecraftiana of the first season of True Detective (2014).

\section{Works Cited}

Armstrong, Paul B. How Literature Plays with the Brain: The Neuroscience of Reading and Art. Baltimore, MD: Johns Hopkins University Press, 2013. Print.

Attebery, Brian. Stories about Stories: Fantasy and the Remaking of Myth. New York, NY: Oxford University Press, 2014. Print.

Campbell, Joseph. The Hero With a Thousand Faces. 1949. Commemorative ed. Princeton, NJ: Princeton University Press, 2004. Print.

Čipkár, Ivan. "The Cognitive Model of the Vampire and Its Accommodation in the Twentieth Century." Moravian Fournal of Literature and Film, vol. 5, no. 1. 2014: 23-44. Print.

Delahay, Matti. Imaginary Things: Modern Myth in Neil Gaiman's American Gods (2001). 2009. University of Jyväskylä, Master's thesis.

Eliot, T. S. "Ulysses, Order and Myth." 1923. Selected Prose of T. S. Eliot. Ed. Frank Kermode. New York, NY: Harcourt, 1975 · 175-178. Print.

Freud, Sigmund. "The Uncanny." Trans. David McLintock. The Uncanny. New York: Penguin, 2003. Print.

Frye, Northrop. Anatomy of Criticism: Four Essays. 1957. Princeton, NJ: Princeton University Press, 2000. Print.

Gaiman, Neil. Violent Cases. London: Escape Books, 1987. Print.

---. with M. John Harrison, Terry Pratchett, Geoff Ryman, and Diana Wynne Jones. "Whose Fantasy?" Hosted by Neil Gaiman. One of a series of events examining British genre fiction. London: Institute of Contemporary Arts. 1988. Web. Accessed 1 June 2018. sounds.bl.uk/Arts-literature-and-performance/ ICA-talks/o24M-Coo95Xo364XX-o10oVo.

---. Neverwhere. 1996. London: Headline Review, 2005. Print.

---. Smoke and Mirrors: Short Fictions and Illusions. London: Headline Review, 1999. Print.

---. "Neil Gaiman: Man in Black." Interview. AAR. 12 April 1999. Web. 
Accessed 1 June 2018. allaboutromance.com/author-interviews/neil-gaimaninterview/.

---. "A Conversation with Neil Gaiman." Interview by Claire E. White. The Internet Writing fournal. March 1999. Web. Accessed 1 June 2018. www. writerswrite.com/journal/marg9/a-conversation-with-neil-gaiman-3991.

---. "Reflections on Myth (with Digressions into Gardening, Comics, and Fairy Tales)." Columbia: A Journal of Literature and Art, vol. 31, winter.1999: 75-84. Print.

---. American Gods. 2001. London: Headline Review, 2005. Print.

---. 3 Feb. journal entry. Neil Gaiman's fournal. 2003. Web. 1 June 2018. journal. neilgaiman.com/2003/o2/long-occasionally-frustrating.asp.

---. Anansi Boys. New York, NY: Morrow, 2005. Print.

---. Fragile Things: Short Fictions and Wonders. London: Headline Review, 2007. Print.

---. "Myth, Magic, and the Mind of Neil Gaiman: A Conversation with the Dream King." Interview by Tim E. Ogline. Wild River Review. 2007. Web. Accessed 1 June 2018. www.wildriverreview.com/columns/pen-world-voices/ myth-magic-and-the-mind-of-neil-gaiman/.

---. Interview by Lisa-Ann Lee. SG Magazine. 20 Nov. 2009. Web. 1 June 2018. sg.asia-city.com/events/article/first-person-neil-gaiman.

--.. "Neil Gaiman's Opinion on Fanfiction.” Tumblr. 24 April 2012. Web. 1 June 2018. neil-gaiman.tumblr.com/post/21746253134/neil-gaimans-opinion-onfanfiction.

---. The Ocean at the End of the Lane. New York, NY: William Morrow, 2013. Print.

--- A Calendar of Tales. Keep Moving. Internet ad campaign. BlackBerry. Feb. 2013. Web. 1 June 2018. https://crackberry.com/keep-moving-projects

---. The Sleeper and the Spindle. London: Bloomsbury, 2014. Print.

---. Trigger Warning: Short Fictions \& Disturbances. London: Headline Review, 2015. Print.

---. "Neil Gaiman at the Douglas Adams Memorial Lecture 2015." YouTube. Save the Rhino International. 3 March 2015. Web. 1 June 2018. www.youtube. com/watch?v=D8UU-F1Yorg.

Gibbons, Alison. "Postmodernism Is Dead. What Comes Next?" The Times Literary Supplement. 12 June 2017. Web. Accessed 1 June 2018. www.the-tls. co.uk/articles/public/postmodernism-dead-comes-next/.

Hogan, Patrick Colm. Beauty and Sublimity: A Cognitive Aesthetics of Literature and the Arts. Cambridge: Cambridge University Press, 2016. Print. 
Hutcheon, Linda. The Politics of Postmodernism. 2nd ed. London: Routledge, 2002. Print.

Kirby, Alan. "The Death of Postmodernism and Beyond." Philosophy Now, vol. 58, Nov-Dec, 2006. Web. Accessed 1 June 2018. philosophynow.org/ issues/58/The_Death_of_Postmodernism_And_Beyond.

Klapcsik, Sandor. Liminality in Fantastic Fiction: A Poststructuralist Approach. Jefferson, NC: McFarland \& Co., 2012. Print.

Kulka, Tomáš. Umění a kýč. Prague: Torst, 1994. Print.

Lukach, Katherine M. Transformative Encounters in the Works of Neil Gaiman. 2007. University of North Carolina, Master's thesis.

Lyotard, Jean-Francois. The Postmodern Condition: A Report on Knowledge. Translated by Geoff Bennington and Brian Massumi. Manchester: Manchester University Press, 1984. Print.

Onega, Susana. "The Mythical Impulse in British Historiographic Metafiction." European fournal of English Studies, vol. 1, no. 2. 1997: 184-204. Print.

Percy, Benjamin. "It All Floods Back: Neil Gaiman's Ocean at the End of the Lane." Review. New York Times. 27 June 2013. Web. Accessed 1 June 2018. www.nytimes.com/2013/o6/30/books/review/neil-gaimans-ocean-at-theend-of-the-lane.html.

Rauch, Stephen. Neil Gaiman's The Sandman and Joseph Campbell: In Search of the Modern Myth. Cabin John, MD: Wildside Press, 2003. Print.

Schank, Roger C. and Robert P. Abelson. Scripts, Plans, Goals and Understanding: An Inquiry into Human Knowledge Structures. Hillsdale, NJ: Lawrence Erlbaum Associates Publishers, 1977. Print.

Tompkins, Jane. Sensational Designs: The Cultural Work of American Fiction $1790-$ 1860. Oxford: Oxford University Press, 1986. Print.

Vuust, Peter and Morten Kringelbach. "The Pleasure of Music." Pleasures of the Brain, Eds. Morten Kringelbach and Kent Berridge. Oxford: Oxford University Press, 2010. 255-269. Print.

Widdowson, H. G. Practical Stylistics. Oxford: Oxford University Press, 1992. Print.

\section{Acknowledgements}

The paper was supported by MŠMT, grant IGA_FF_2018_o31 (Nové formy vyprávění v post-postmoderní angloamerické literatuře). 
This paper is comprised of parts of the text of chapter four and of the conclusion of Ivan Čipkár's doctoral dissertation More than True: Cognitive Universals in a Reader Response Analysis of Neil Gaiman.

IVAN ČIPKÁR holds a Ph.D. in English and American Literature, having graduated from Palacký University Olomouc in 2018. His doctoral thesis is concerned with cognitive literary universals, reader response, and the works of Neil Gaiman in the context of post-postmodernism. His recent published articles include "The Girl Who Prospered: The Implied Author as an Integrative Hermeneutic Device in Angela Carter's 'The Werewolf'” and "The Cognitive Model of the Vampire and Its Accommodation in the Twentieth Century". He is currently interested in philosophical critique of semantic externalism in the American analytic tradition.

ivan.cipkar@outlook.com 